\title{
INTERNSHIPS IN PHARMACEUTICAL STUDENTS’ DEVELOPMENT
}

\author{
DRAGOȘ FLORIAN CIOLAN ${ }^{1}$, CĂTĂLINA LILIANA ANDREI ${ }^{2 *}$, ANDREEA MIRICĂ $^{3}$, IULIA \\ ELENA TOMA ${ }^{3}$, DOINA DRĂGĂNESCU ${ }^{4}$, FLAVIAN ȘTEFAN RĂDULESCU ${ }^{1}$
}

1 "Carol Davila” University of Medicine and Pharmacy, Centre for Drug Sciences (CedS), Bucharest, Romania

2 "Carol Davila" University of Medicine and Pharmacy, Department of Cardiology and Thoracic Pathology, Bucharest, Romania

${ }^{3}$ Bucharest University of Economic Studies, Faculty of Economic Cybernetics, Statistics and Informatics, Statistics and Econometrics Department, Bucharest, Romania

4 "Carol Davila" University of Medicine and Pharmacy, Department of Pharmaceutical Physics and Informatics, Bucharest, Romania

*corresponding author: ccatalina97@yahoo.com

Manuscript received: September 2019

\begin{abstract}
The primary purpose of a pharmacist today, is, as it usually has been, to be in the service of human health. This aim can be achieved through a large number of professional possibilities. In this context, pharmacy students need a wide variety of skills, in addition to basic biology and chemistry notions. The main objective of this paper is to explore how should pharmacy higher education institutions in Romania adapt so that they prepare graduates to make the transition from academic training to joining the workforce.
\end{abstract}

\section{Rezumat}

Scopul principal al unul farmacist, este, așa cum a fost dintotdeauna, să fie în slujba sănătății. Acest scop poate fi atins prin multiple posibilităţi profesionale. În acest context studenții farmaciști au nevoie de multe aptitudini, în plus față de cunoștințele de bază de biologie și chimie. Principalul obiectiv al lucrării este să exploreze cum pot insitutuțiile de învățământ din România să își adapteze curricula astfel încât studenții din cadrul specializării farmacie să facă tranziția spre piața muncii.

Keywords: internship, pharmacy, Kruskal-Wallis H Test

\section{Introduction}

The global labour market is experiencing major transformations due to several economic factors (the changing nature of work, climate change, geopolitical volatility) and technological advances (mobile internet, cloud technologies, big data), in the context of resource constraints, pressure for short term profitability and relatively underprepared workforce as a result to an old curriculum [52]. This is why professions and organizations must increase their efforts to change significantly in order to fully adapt to the demands and pressures of internal and external stakeholders [17].

Healthcare is a sector that needs special attention, due to the special relationship established between clients (patients), providers (organizations) and practitioners (professionals) that can be described as follows: the interest of clients are almost always consistent with the interests of professionals but not always consistent with the interests (limited or brad) of the providers [11]. Furthermore, of all healthcare branches, pharmacy is the most sensitive one as "two views can be found in the historically anchored conflict the profession has been struggling with since its conception: business interests vs professional interests" [48]. Moreover, one should note that there is an agreement among pharmacists, as professionals in one of the most flourishing industries of the world [44], that they must "adapt and transform", detaching themselves from "archaic practices" [21]. However, one should note that the world they must adapt to is dominated by the desire of increased efficiency and predictability, of developing quantifiable measures and standardization [40]

Given the complexity of the pharmaceutical sector, this paper aims to explore how pharmacy higher education institutions in Romania should adapt such that they prepare graduates to make the transition from school to work smoothly. In order to achieve this purpose, firstly, an in-depth analysis of the pharmacy profession will be performed, emphasizing the main transformation drivers. Secondly, the main skills a pharmacist is today required to possess are briefly presented. Thirdly, an analysis of pharmacy internships is performed, as internships are a key link between students, universities and employers.

One should note that the Romanian higher education area has several particularities. Firstly, the educational programs as well as the research undertaken have a relatively low international visibility, both in scientific databases as well as on the internet [8, 30, 31, 47]. Secondly, during the transition period, Romania 
experienced a decline in the number of inhabitants (a phenomenon occurring also in the neighbouring countries) and an increase in the school dropout, with long term dramatic consequences for the higher education area $[4,9,10]$. Thirdly, the resources within the educational system are not appropriately managed [13]. Finally, enrolling in higher education is often seen as an alternative to unemployment [29]. The healthcare system in Romania has experienced a long and complex reform process [5]. This process occurred on the background of the reform of the entire Romanian public administration, in the attempt to combat corruption $[6,7]$. Moreover, several new ethical considerations occurred in this profession [39].

One should note that even if most of the pharmacy graduates are working in community pharmacies, there are many other career possibilities, ranging from jobs within the pharmaceutical industry, usually preferred in the long run, to medical marketing, usually preferred in the short run [15]. Further, pharmacists are the ones that must mediate between healthcare policymakers (politicians in charge of allocating funds within the healthcare system), public health policymakers (those in charge of guaranteeing drug safety and quality) and industrial policy makers (those in charge of maximizing profits for their organisations) [48]. Moreover, pharmacists are seen from two contradictory perspectives: providers of free medical advice and sellers of hardly affordable drugs [19]. Finally, pharmacy is no longer seen as a "second choice career", "an option to the medical degree" [37].

The role of pharmacists is closely related to the type of the organisation they are part of and may have particular challenges. Community pharmacists usually must provide medical advice to consumers that are strongly convinced they have enough expertise to treat themselves or seek immediate benefits ignoring potential high risks [22]. Clinical pharmacists have two key functions within the clinical decision making process: reduce the risk that patients face (for example, through assessing dosages) and disease management (for example, through medicine optimisation) [14]. Career opportunities and the complex reality within the healthcare system, as well as the challenges that arose with the economic and social development are key transformation causes. Thus, the traditional role of pharmacists as informal and free of charge advisors evolved to that of essential health care providers [2], as well as patient-centred care service providers [27]. Given the evolving role of pharmacists, "clinical knowledge and skill may not be sufficient to ensure the leadership required to coordinate and provide effective pharmaceutical services" [25]. There is a wide variety of skills pharmacists need.

Firstly, there is a need for business decision making competences [42]. Such skills include: ethical standards, communication skills, strategic and multidimensional thinking, an in-depth understanding of the healthcare system, teamwork and collaborative skills [16, 25, 41].

Secondly, there is a need for analytical and computational skills. For example, it is crucial for pharmacists to master quantitative and qualitative techniques in order to be able to measure customer satisfactions [12]. Also, in order to be able to assess and perform studies that are aimed at minimising the risk of new marketed drugs, pharmacists need to be able to operate with large data sets [33]

Thirdly, pharmacists need social skills [50]. These include a high capacity for adaptability [24].

In order to impart these skills to students, the pharmacy curriculum, besides the latest technical skills within natural sciences [49], must incorporate knowledge from many other areas: legal, accounting, public relations, advertising, sales, marketing, teaching, coaching, entrepreneurship [1]. Moreover, it must be adapted to the local needs [23]. Other skills and attitudes that higher education should provide to pharmacy students are: critical thinking [18], creative problem solving [38] and the real time knowledge to recommend medicines [36].

\section{Materials and Methods}

In order to assess the skills internships provide to pharmacy students, the questionnaire proposed in a previously published article was used [3]. We distributed the questionnaire to pharmacy students in the $4^{\text {th }}$ year of studies, 242 students answered to our call.

Based on this questionnaire, several variables were defined (Table I). Four variables concern the demographic characteristics of the respondents. 6 variables deal with practical aspects of the pharmacy profession. 1 variable measures the status on the labour market of the respondents. Moreover, based on this questionnaire one can elaborate a framework for assessing the students' status on the labour market and their perception with regard to internship programs that any university providing pharmacy education should use. Based on the data we collected, we offer an example on how the results should be published, increasing the transparency of the universities towards their future students 
Variable description, source: designed by the authors

\begin{tabular}{|c|c|}
\hline Variable & Description \\
\hline Gender & 2 categories: 0 is attributed to females, 1 is attributed to males \\
\hline $\begin{array}{l}\text { Primary source } \\
\text { of income }\end{array}$ & $\begin{array}{l}6 \text { categories: } 1 \text { - is for scholarship for good results, } 2 \text { - study scholarship, } 3 \text { - wage, } 4 \text { - social scholarship, } \\
5 \text { - family support, } 6 \text { - other }\end{array}$ \\
\hline Monthly income & $\begin{array}{l}5 \text { categories: } 1 \text { - below } 500 \text { lei, } 2 \text { - between } 500 \text { and } 1000 \text { lei, } 3 \text { - between } 1000 \text { and } 1500 \text { lei, } 4-\text { between } \\
1500 \text { and } 2000 \text { lei, } 5 \text { - over } 2000 \text { lei }\end{array}$ \\
\hline Place o & $\begin{array}{l}2 \text { categories: } 1 \text { - the place of study is the same as the place of birth; } 0 \text { - the place of study is different from } \\
\text { the place of birth }\end{array}$ \\
\hline $\begin{array}{l}\text { Practical } \\
\text { applications of } \\
\text { the literature }\end{array}$ & $\begin{array}{l}\text { Represents the extent to which students have managed to familiarize with the practical applications of the } \\
\text { literature mandatory in any pharmacy. It is the mean of three ordinal } 5 \text { ascending scale variables: the extent } \\
\text { to which students have managed to familiarize with the practical applications of the specific legislation, the } \\
\text { European Pharmacopeia X Edition and the Nomenclature of Medicinal Products for Human Use, respectively. }\end{array}$ \\
\hline Logistic & $\begin{array}{l}\text { Represents the extent to which students got involved with logistic activities. It is the mean of five ordinal } 5 \\
\text { ascending scale variables: the extent to which students got involved with developing a list of suppliers/ } \\
\text { warehouses, negotiating payment terms with suppliers, negotiating delivery terms with suppliers, } \\
\text { negotiating discounts with suppliers, drawing up a contract, respectively. }\end{array}$ \\
\hline Drug re & $\begin{array}{l}\text { Represents the extent to which students got involved with drug reception activities. It is the mean of three } \\
\text { ordinal } 5 \text { ascending scale variables: the extent to which students got involved with invoice reception, } \\
\text { quantitative reception and qualitative reception, respectively. }\end{array}$ \\
\hline Mark & $\begin{array}{l}\text { Represents the extent to which students got involved with marketing activities. It is the mean of five } \\
\text { ordinal 5-scale variables: enhancement of the marketing strategy, setting the price for OTC drugs, setting } \\
\text { the price for prescription drugs, setting the price for magisterial drugs, setting the price for officinal drugs. }\end{array}$ \\
\hline Drug pre & $\begin{array}{c}\text { Represents the extent to which students got involved with the drug preparation process. It is a } 5 \text { ascending } \\
\text { scale variable. }\end{array}$ \\
\hline Patients & $\begin{array}{l}\text { Represents the extent to which students managed to develop their abilities to communicate with the } \\
\text { patients. It is a } 5 \text { ascending scale variable. }\end{array}$ \\
\hline $\begin{array}{l}\text { Labour market } \\
\text { status }\end{array}$ & $\begin{array}{c}3 \text { categories: } 0 \text { - the respondent is not employed; } 1 \text { - the respondent is working in other fields; } 2-\text { the } \\
\text { respondent is working within the pharmacy field. }\end{array}$ \\
\hline
\end{tabular}

In order to analyse the differences in the variables related to professional aspects of the pharmacy profession with regard to the demographic characteristics and labour market status, the Kruskal-Wallis H Test was employed. The data answers the perquisite conditions for applying this test as presented in [26], namely: the dependent variables are ordinal (drug preparation, patients) or interval - ratio (practical applications of the literature, logistic, drug reception, marketing); the independent variable is nominal, with mutually exclusive categories: gender, primary source of income, monthly income, place of study, labour market status; it can't be presumed that the distributions have the same variability, therefore only the mean rank will be compared.

As the Kruskal-Wallis $\mathrm{H}$ Test is an omnibus test, a post-hoc test was run when more than two categories had to be compared. Moreover, in such cases, the results are reported using the Bonferroni correction, namely p-values for pairwise results comparisons are multiplied by the number of categories [20].

\section{Results and Discussion}

Respondents have the following demographic characteristics: $88 \%$ are females, $75 \%$ stated that their primary income source is their family, $80 \%$ have monthly incomes below 1500 lei, and approximately $75 \%$ study outside their hometown. Therefore the study covers a relevant student population with a wide range of characteristics.

Drug preparation and interacting with the patients are mandatory activities in pharmacy internships, integrated within the curriculum. Approximately $60 \%$ of the respondents declared that they got involved at least moderately with such activities during their internship. Figures 1 to 4 display the extent to which students got involved with various internship activities, other than drug preparation and interaction with the patient.

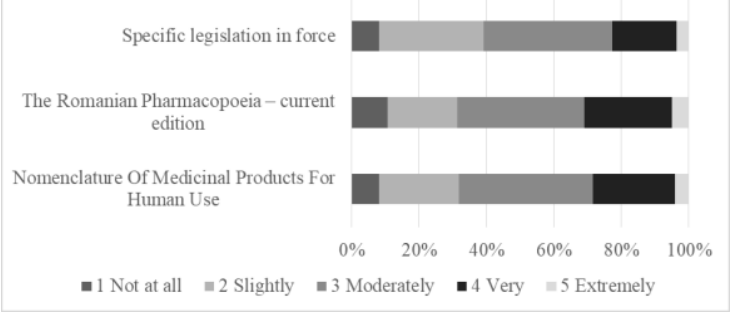

Figure 1.

The extent to which students have managed to familiarize themselves with the practical applications of the literature mandatory in any pharmacy, source: designed by the authors based on data collected through the questionnaire

Figure 1 displays the extent to which students have managed to familiarize themselves with the practical applications of the literature mandatory in any pharmacy. 
As one can observe, approximately $60 \%$ of the students managed to familiarize themselves with the specific legislation at least moderately. $80 \%$ of the students got familiar with the current edition of the Pharmacopeia and the Nomenclature of Medicinal Products for Human Use, respectively.

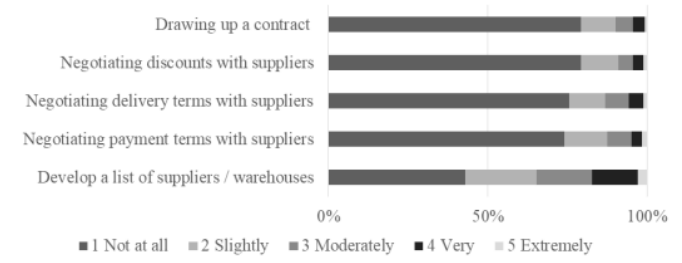

Figure 2.

The extent to which students got involved with logistic activities, source: designed by the authors based on data collected through the questionnaire

Figure 2 displays the extent to which students got involved with logistic activities. As one can observe, students usually don't get involved with such activities during internships, except for developing lists of warehouses or suppliers. The extent to which students got involved with medication reception activities is displayed in Figure 3. As can be seen, students usually participate at activities.

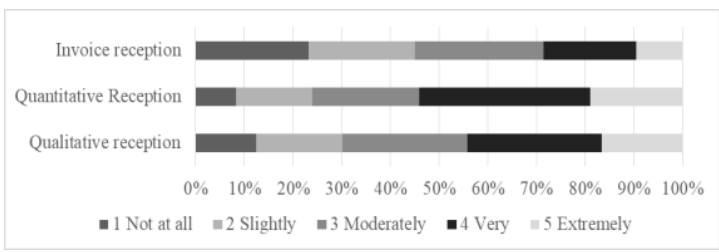

Figure 3.

The extent to which students got involved with medication reception activities, source: designed by the authors based on data collected through the questionnaire

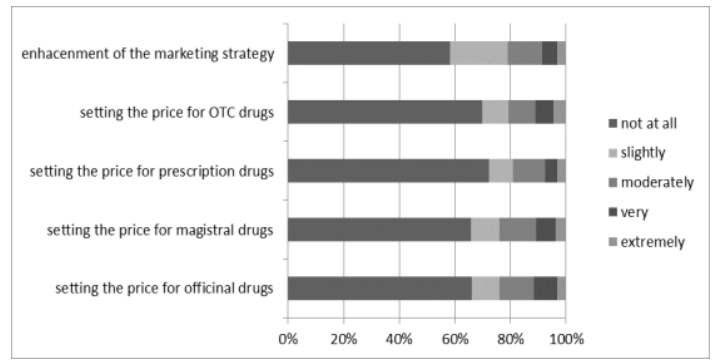

Figure 4.

The extent to which students got involved into marketing activities, source: designed by the author based on data collected through questionnaire

Figure 4 displays the extent to which students got involved with marketing activities. As one can observe, students were not usually engaged into such activities. Only approximately $40 \%$ of the respondents reported that they participated in the enhancement of the drugstore's marketing strategy at least moderately. Figure 5 displays the students' status on the labour market and within the domain, while Figure 6 displays the students' perception of working in the pharmacy domain with regard to internship and their relationship with the university. As one can observe, most students don't work and those who do, work in a different domain. Moreover, students working in the pharmacy domain stated that the internship was helpful for their professional development.

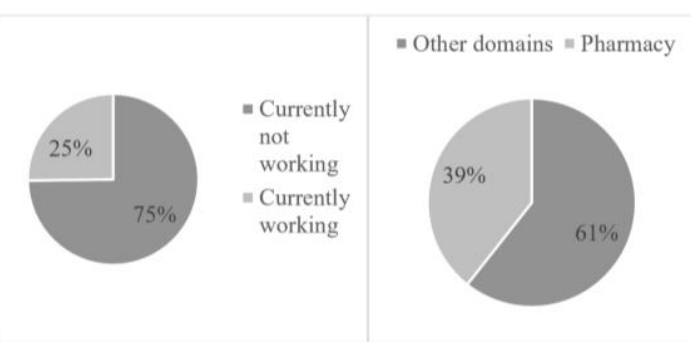

Figure 5.

Pharmacy students status on the labour market (left) and domain (right), source: designed by the author based on data collected through questionnaire

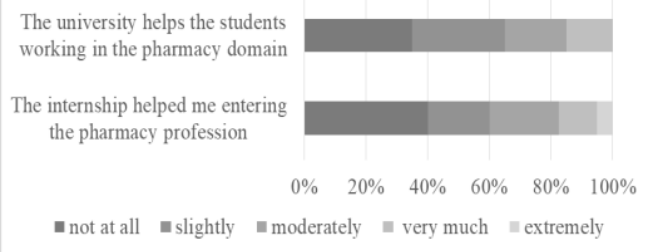

Figure 6.

Students' perception of working in the pharmacy domain with regard to internship and their relationship with the university, source: designed by the author based on data collected through questionnaire

As one can observe from Figure 7, students that declared they worked in other domains stated that the abilities and knowledge studies provided them don't match the requests of the employees. With regard to the reasons why most students don't work, on can observe that the lack of time is prevalent (Figure 8).

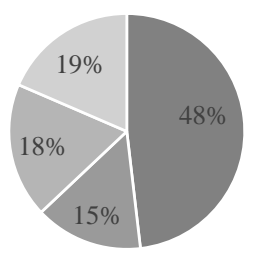

- The abilities and knowledge studies provided the students don't match the requests of the employers - Jobs are scarce

- Jobs are underpaid

= Doesn't like the domain

Figure 7.

Why do some students choose to work in other areas than pharmacy?, source: designed by the author based on data collected through questionnaire 
FARMACIA, 2020, Vol. 68, 1

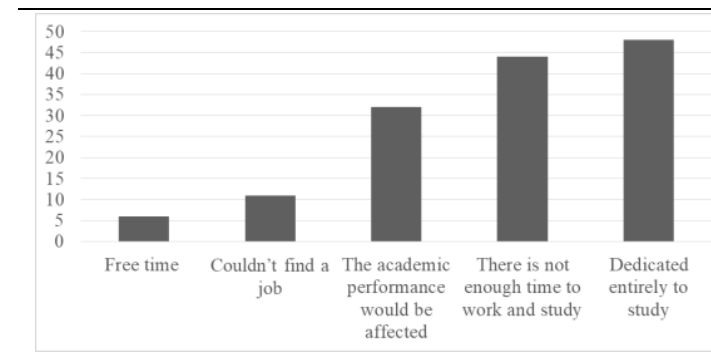

Figure 8.

Reasons for not working, source: designed by the author based on data collected through questionnaire

Table II displays the results of the Kruskal-Wallis $\mathrm{H}$ Test. As it can depicted, there are no significant differences with regard to gender and monthly income. There are significant differences in the extent that students familiarize themselves with the practical applications of the mandatory literature during their internship across the categories of the primary source of income. The same results were obtained for the variable showing the extent to which students managed to develop their abilities to communicate with the patients. There is a significant difference in the extent students got involved with drug preparation with regard to the location of their university relatively to their birthplace. Those who study outside their hometown got involved with the process of drug preparation to a greater extent than those who study in their home town. The labour market status generated the highest number of differences in the dependent variables, as follows: logistic activities, drug reception, marketing and patients. These findings are not surprising, as working students are usually motivated by gaining experience in order to have a competitive advantage on the labour market in the future [35]. Moreover, it has been demonstrated that students getting involved into practical activities are more likely to pursue a career in the desired domain [45] therefore it is only natural for working students to be actively engaged in the internship program.

Kruskal-Wallis H Test results (mean ranks and significance between categories), source: designed by the authors, based on data collected through the questionnaire

\begin{tabular}{|c|c|c|c|c|c|c|c|}
\hline \multirow{2}{*}{$\begin{array}{l}\text { Independent } \\
\text { variable }\end{array}$} & \multirow{2}{*}{$\begin{array}{l}\text { Category of each } \\
\text { independent } \\
\text { variable }\end{array}$} & \multicolumn{6}{|c|}{$\begin{array}{l}\text { Mean ranks and significance of each of the following dependent variable with regard to } \\
\text { the defined categories of the independent variable: }\end{array}$} \\
\hline & & $\begin{array}{c}\text { Practical applications of } \\
\text { the literature }\end{array}$ & $\begin{array}{l}\text { Logistic } \\
\text { activities }\end{array}$ & $\begin{array}{c}\text { Drug } \\
\text { reception }\end{array}$ & Marketing & $\begin{array}{c}\text { Drug } \\
\text { preparation }\end{array}$ & Patients \\
\hline \multirow{3}{*}{ Gender } & 0 & 123.15 & 119.77 & 123.29 & 119.72 & 124.64 & 121.13 \\
\hline & 1 & 109.38 & 134.17 & 108.36 & 134.55 & 98.43 & 124.21 \\
\hline & Sig. & 0.286 & 0.217 & 0.266 & 0.213 & 0.052 & 0.819 \\
\hline \multirow{7}{*}{$\begin{array}{l}\text { Primary source } \\
\text { of income }\end{array}$} & 1 & 50.86 & 95.00 & 94.36 & 90.79 & 102.21 & 39.79 \\
\hline & 2 & 118.33 & 127.35 & 130.23 & 132.60 & 116.96 & 110.31 \\
\hline & 3 & 138.56 & 113.25 & 133.25 & 97.25 & 158.69 & 161.81 \\
\hline & 4 & 136.57 & 129.79 & 135.21 & 122.39 & 101.79 & 159.11 \\
\hline & 5 & 123.85 & 122.00 & 120.70 & 121.41 & 123.31 & 121.67 \\
\hline & 6 & 88.75 & 103.75 & 91.83 & 142.33 & 105.50 & 118.75 \\
\hline & Sig. & 0.046 & 0.451 & 0.617 & 0.451 & 0.457 & 0.003 \\
\hline \multirow{6}{*}{ Monthly income } & 1 & 136.18 & 129.03 & 129.29 & 137.83 & 135.19 & 110.65 \\
\hline & 2 & 115.97 & 119.26 & 112.57 & 114.39 & 119.40 & 116.94 \\
\hline & 3 & 116.55 & 119.84 & 126.10 & 110.33 & 120.44 & 120.72 \\
\hline & 4 & 125.68 & 127.15 & 122.97 & 134.03 & 110.06 & 135.69 \\
\hline & 5 & 111.50 & 102.84 & 128.94 & 116.72 & 116.44 & 154.66 \\
\hline & Sig. & 0.395 & 0.568 & 0.611 & 0.079 & 0.519 & 0.132 \\
\hline \multirow{3}{*}{ Place of study } & 0 & 121.58 & 120.50 & 123.32 & 120.58 & 127.26 & 122.29 \\
\hline & 1 & 121.23 & 124.67 & 115.72 & 124.41 & 103.24 & 119.01 \\
\hline & Sig. & 0.971 & 0.638 & 0.457 & 0.673 & 0.019 & 0.748 \\
\hline \multirow{4}{*}{$\begin{array}{c}\text { Labour market } \\
\text { status }\end{array}$} & 0 & 117.26 & 115.87 & 117.68 & 113.56 & 121.30 & 115.28 \\
\hline & 1 & 139.72 & 130.81 & 112.20 & 140.59 & 130.59 & 141.42 \\
\hline & 2 & 125.40 & 149.63 & 164.67 & 151.96 & 109.00 & 137.71 \\
\hline & Sig. & 0.155 & 0.018 & 0.004 & 0.001 & 0.481 & 0.047 \\
\hline
\end{tabular}

The results of the post-hoc test are displayed in Table III. Those who declared that their primary source of income is a scholarship for good academic results managed to familiarize themselves better with the practical applications of the literature mandatory in any pharmacy compared to their colleagues whose primary income comes from wage or family. Similar results were obtained in the case of the "patients" variable. Students who receive a scholarship for good academic results are usually highly committed to their studies. The results obtained indicated that motivation for studying is one of the key factors in increasing the extent to which students involve themselves in internship activities. Therefore, it is crucial to keep 
students motivated towards learning from the first year of university. Literature offers various methods in this respect: casework, guided discussions, experiential learning [51] integrating innovative technologies within courses [53] and integrating research activities [28].
Regardless of the method they choose, in order to provide students a fruitful education experience teachers must bear in mind that "a teacher is not teaching but rather facilitates learning" through encouraging students "to find their own knowledge" [46].

Table III

Post-hoc test results; source: designed by the authors, based on data collected through questionnaire

\begin{tabular}{|c|c|c|}
\hline Independent & Dependent & Sample 1 - Sample 2 (Test statistic, Std. Error) \\
\hline \multirow{30}{*}{ Primary source of income } & \multirow{15}{*}{ Practical applications of the literature } & $1-6(-37.893 ; 36.312)$ \\
\hline & & $1-2(-67.470 ; 27.792)$ \\
\hline & & $1-5 * *(-72.996 ; 25.142)$ \\
\hline & & $1-4 * *(-85.714 ; 30.780)$ \\
\hline & & $1-3(-87.705 ; 33.780)$ \\
\hline & & $6-2(26.577 ; 29.561)$ \\
\hline & & $6-5(35.104 ; 27.084)$ \\
\hline & & $6-4(47.821 ; 31.848)$ \\
\hline & & $6-3(49.812 ; 35.249)$ \\
\hline & & $2-5(-5.527 ; 13.689)$ \\
\hline & & $2-4(-18.245 ; 21.636)$ \\
\hline & & $2-3(-20.236 ; 26.388)$ \\
\hline & & $5-4(12.718 ; 18.108)$ \\
\hline & & $5-3(14.709 ; 23.580)$ \\
\hline & & $4-3(1.991 ; 28.927)$ \\
\hline & \multirow{15}{*}{ Patients } & $1-2(-70.552 ; 28.834)$ \\
\hline & & $1-6(-78.964 ; 37.673)$ \\
\hline & & $1-5^{*}(-81.883 ; 26.084)$ \\
\hline & & $1-4 *(-119.321 ; 31.346)$ \\
\hline & & $1-3 *(-122.027 ; 35.046)$ \\
\hline & & $2-6(-8.442 ; 30.669)$ \\
\hline & & $2-5(-11.361 ; 14.202)$ \\
\hline & & $2-4(-48.799 ; 22.447)$ \\
\hline & & $2-3(-51.505 ; 27.377)$ \\
\hline & & $6-5(2.919 ; 28.099)$ \\
\hline & & $6-4(40.35 ; 33.041)$ \\
\hline & & $6-3(43.062 ; 36.570)$ \\
\hline & & $5-4(37.439 ; 18.784)$ \\
\hline & & $5-3(40.144 ; 24.464)$ \\
\hline & & $4-3(2.705 ; 30.011)$ \\
\hline \multirow{12}{*}{ Labour market status } & \multirow{3}{*}{ Logistic activities } & $0-1 \quad(-14.943 ; 10.619)$ \\
\hline & & $0-2 *(-33.769 ; 12.786)$ \\
\hline & & $1-2(-18.814 ; 15.427)$ \\
\hline & \multirow{3}{*}{ Drug reception } & $1-0(5.474 ; 12.232)$ \\
\hline & & $1-2 *(-52.464 ; 17.769)$ \\
\hline & & $0-2 *(-46.99 ; 14.728)$ \\
\hline & \multirow{3}{*}{ Marketing } & $0-1 *(-27.037 ; 10.864)$ \\
\hline & & $0-2 *(-38.400 ; 13.081)$ \\
\hline & & $1-2(-11.364 ; 15.783)$ \\
\hline & \multirow{3}{*}{ Patients } & $0-1(-22.429 ; 14.710)$ \\
\hline & & $0-2 * *(-26.14 ; 12.217)$ \\
\hline & & $1-2(3.711 ; 17.748)$ \\
\hline
\end{tabular}

Students working in a pharmacy involved themselves significantly more in logistic activities during the internship compared to students who are not employed. Similar results were obtained for drug preparation, marketing activities and the extent to which students managed to improve their abilities to communicate with the patients. Such skills are essential, so that the future professionals manage their careers in a competitive environment [43], therefore it is essential that universities find innovative ways to incorporate such skills. An example in this respect is using softwares that enable students to experiment interaction with the patient through simulations [32].

The usefulness of internship, from graduates' perception will be assessed. In this respect, a short questionnaire was distributed to recent pharmacy graduates. The questionnaire can be found in Andrei et al. The total number of respondents was 70, 27\% males and $73 \%$ females. The mean age was 29 and their average monthly income was approximately 3980 lei. Over 
FARMACIA, 2020, Vol. 68, 1

$50 \%$ of the respondents believe that their studies provide them suitable skills for the labour market while their internship helped them very much in finding a job and should be considered practical activity. However, $75 \%$ of the respondents consider that formal education within the pharmacy area don't incorporate enough practical activities. Also, 26\% of the respondents consider that a foreign language and computer skills would be very useful on the labour market yet are insufficiently covered on the labour market.

Table IV contains the variables that are defined based on the questionnaire content.

Table IV

Variables defined based on the questionnaire in Andrei et al. [3]

\begin{tabular}{|c|c|}
\hline Variable name & Description \\
\hline $\begin{array}{l}\text { Extent suitable } \\
\text { skills }\end{array}$ & $\begin{array}{l}\text { Assesses to what extent the respondents believe that their formal education provided them with the suitable } \\
\text { skills for the labour market } \\
\text { (1 - not at all, } 2 \text { - slightly, } 3 \text { - moderately, } 4 \text { - very much, } 5 \text { - extremely) }\end{array}$ \\
\hline $\begin{array}{l}\text { Extent internship } \\
\text { find job }\end{array}$ & $\begin{array}{l}\text { Assesses to what extent the respondents believe that their internship helped them find a job } \\
\text { ( } 1 \text { - not at all, } 2 \text { - slightly, } 3 \text { - moderately, } 4 \text { - very much, } 5 \text { - extremely) }\end{array}$ \\
\hline $\begin{array}{c}\text { Extent practical } \\
\text { classes }\end{array}$ & $\begin{array}{l}\text { Assesses to what extent the respondents believe that their formal education include enough practical } \\
\text { activities ( } 1 \text { - not at all, } 2 \text { - slightly, } 3 \text { - moderately, } 4 \text { - very much, } 5 \text { - extremely) }\end{array}$ \\
\hline Competencies & $\begin{array}{l}\text { Assesses the main skills that formal education did not cover enough } \\
\text { (Speaking a foreign language at a professional level, Computer skills, Communication, Marketing, Accounting) }\end{array}$ \\
\hline $\begin{array}{c}\text { Extent } \\
\text { internships as } \\
\text { practical activity }\end{array}$ & $\begin{array}{l}\text { Assesses to what extent the respondents believe that individual internships should be considered formal } \\
\text { practical activity and receive ECTS } \\
\text { (1 - not at all, } 2 \text { - slightly, } 3 \text { - moderately, } 4 \text { - very much, } 5 \text { - extremely) }\end{array}$ \\
\hline $\begin{array}{l}\text { Professional } \\
\text { opportunities } \\
\text { current job }\end{array}$ & $\begin{array}{l}\text { Assesses to what extent the respondents are satisfied with the professional opportunities at the current job } \\
\qquad(1 \text { - not at all, } 2 \text { - slightly, } 3 \text { - moderately, } 4 \text { - very much, } 5 \text { - extremely })\end{array}$ \\
\hline $\begin{array}{c}\text { Income } \\
\text { satisfaction }\end{array}$ & $\begin{array}{l}\text { Assesses to what extent the respondents are satisfied with their income } \\
\text { (1 - not at all, } 2 \text { - slightly, } 3 \text { - moderately, } 4 \text { - very much, } 5 \text { - extremely) }\end{array}$ \\
\hline Gender & Records the respondent's gender (male/female). \\
\hline Age & Records the respondent's age in years. \\
\hline Monthly income & Records the respondent's monthly income in lei. \\
\hline
\end{tabular}

Table V

Spearman correlation coefficients between the defined variables

\begin{tabular}{|c|c|c|c|c|c|c|c|c|}
\hline & 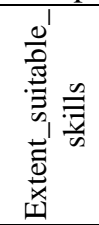 & 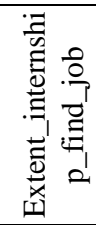 & 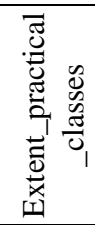 & 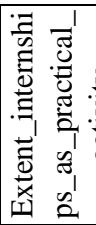 & 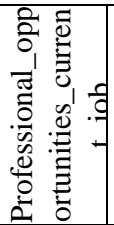 & 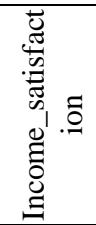 & $\frac{8}{4}$ & 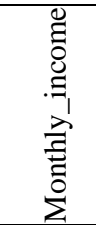 \\
\hline Extent_suitable_skills & 1.00 & $0.39^{* *}$ & $0.54^{* *}$ & 0.03 & $0.29^{*}$ & 0.16 & 0.20 & 0.16 \\
\hline Extent_internship_find_job & $0.39^{* * *}$ & 1.00 & $0.40^{* *}$ & 0.03 & $0.23^{*}$ & $0.29^{*}$ & $0.27^{*}$ & 0.04 \\
\hline Extent_practical_classes & $0.54^{* * *}$ & $0.40^{* *}$ & 1.00 & 0.05 & $0.47^{* *}$ & $0.28^{*}$ & 0.00 & 0.01 \\
\hline Extent_internships_as_practical_activity & 0.03 & 0.03 & 0.05 & 1.00 & 0.20 & $0.30^{*}$ & -0.17 & $0.30^{*}$ \\
\hline Professional_opportunities_current_job & $0.29^{*}$ & $0.23^{*}$ & $0.47^{* *}$ & 0.20 & 1.00 & $0.64^{* *}$ & -0.06 & $0.26^{*}$ \\
\hline Income_satisfaction & 0.16 & $0.29^{*}$ & $0.28^{*}$ & $0.30^{*}$ & $0.64^{* * *}$ & 1.00 & 0.03 & $0.56^{* *}$ \\
\hline Age & 0.20 & $0.27^{*}$ & -0.01 & -0.17 & -0.06 & 0.03 & 1.00 & 0.14 \\
\hline Monthly_income & 0.16 & 0.04 & 0.01 & $0.30^{*}$ & $0.26^{*}$ & $0.56^{* *}$ & 0.14 & 1.00 \\
\hline
\end{tabular}

** Correlation is significant at the 0.01 level (2-tailed), * Correlation is significant at the 0.05 level (2-tailed).

Next, the Spearman correlation was computed between these variables, except for Competencies. The results are presented in Table $\mathrm{V}$.

There is a significant moderate correlation between the extent graduates perceive that formal education provided them with the suitable skills for their future job and the extent they believe that formal education should contain more practical activities. Moreover, the extent internships helped them find a job positively correlates with the satisfaction regarding the professional opportunities at the workplace. Income satisfaction positively correlates with most of the defined variables.
This series of correlations suggest that internships are a fundamental step in a graduate's career development.

\section{Conclusions}

"A profession remains a profession because in the long run - in terms of decades, its members perform a real service to the society" stated Nelson C.F. in 1915, one of the most active members of the Kansas Pharmaceutical Association [34]. To be in the service of society remains the primary purpose of a pharmacist 
today, even though as we have seen, it is transposed in a large number of professional possibilities. As the pharmacists' role is changing, new competencies are needed. Most of these competencies can be acquired through internship programs. There are key competencies that students working within the pharmacy area acquired during internships to a higher level than those who are not employed: developing a list of suppliers/warehouses, negotiating payment terms with suppliers, negotiating delivery terms with suppliers, negotiating discounts with suppliers, drawing up a contract, enhancement of the marketing strategy, setting the price for OTC drugs, setting the price for prescription drugs, setting the price for magisterial drugs, setting the price for officinal drugs, preparing medicines and communicating with patients. Moreover, the results show that students' motivation to learn is essential for their involvement in internship activities. Also, when analysing graduates' perception with regard to internships, one can observe that they perceive it as a vital starting point for their career.

This paper is highly relevant for policy makers that aim to improve the pharmacy curriculum, as it provides useful insights into what future graduates need. Also, it is useful to students as they can choose more suitable internship programs based on these required skills.

\section{Acknowledgement}

This work was financially supported by SOPARD: Career counselling and career guidance for pharmacists SOPARD/161/2.1/G/141846.

\section{Conflict of interest}

The authors declare no conflict of interest.

\section{References}

1. Albert E, What Pharmacy Can Learn From Other Professions. Am J Pharm Educ., 2007; 71(4): 1-4.

2. Anderson S, Community pharmacy and public health in Great Britain, 1936 to 2006: how a phoenix rose from the ashes. J Epidemiol Comm Health, 2007; 61(10): 844-848.

3. Andrei CL, Ciolan DF, Mirica A, Toma IE, Draganescu D, Radulescu FS, Internships and the next generation of pharmacists in Romania. Farmacia, 2019; 67(2): 378-382.

4. Andrei T, Lefter V, Oancea B, Stancu S, A comparative study of some features of higher education in Romania, Bulgaria and Hungary. Rom J Econom Forecast., 2010; 13(2): 280-294.

5. Andrei T, Matei A I, Oancea B, Simultaneous equations models used in the study of some issues related to the corruption and performance of services in the public health system. Theoret App Econom., 2009; 1(530): 3-18.

6. Andrei T, Matei A, Tusa E, Nedelcu M, Characteristics of the Reforming Process in the Romanian Public
Administration System. Transylvan Rev Admin Sci., 2009; 5(25): 13-31.

7. Andrei T, Matei A, Stancu S, Oancea B, Some notes about decentralization process implications on public administration corruption in Romania. Prague Economic Papers, 2009; 18(1): 26-37.

8. Andrei T, Teodorescu D, Mirică A, Beyond the Impact Factor: measuring the international visibility of Romanian social sciences journals. Scientometrics, 2016; 108(1): $1-20$.

9. Andrei T, Teodorescu D, Oancea B, Characteristics and causes of school dropout in the countries of the European Union. Procedia-Social and Behavioral Sciences, 2011; 28: 328-332.

10. Andrei T, Teodorescu D, Oancea B, Iacob A, Evolution of higher education in Romania during the transition period. Procedia-Social and Behavioral Sciences, 2010; 9: 963-967.

11. Bourgeault IL, Hirschkorn K, Sainsaulieu I, Relations between professions and organizations: More fully considering the role of the client. Professions and Professionalism, 2011; 1(1): 67-86.

12. Cavaco AM, Dias JS, Bates IP, Consumers' perceptions of community pharmacy in Portugal: a qualitative exploratory study. Pharm World Sci., 2005; 27(1): 54-60.

13. Dascălu ED, Mirică A, Mincu-Radulescu GI, Pursuing higher education: Privileged or free access in Romania? Rom Statist Rev., 2016; 3: 3-18.

14. Duffull SB, Wright DF, Marra CA, Anakin MG, A philosophical framework for pharmacy in the $21^{\text {st }}$ century guided by ethical principles. Res Soc Admin Pharm., 2018; 14(3): 309-316.

15. El-Hammadi M, Career preferences of Syrian students and their attitudes toward a number of practice areas: Will community pharmacy continue to dominate the profession?. Cur Pharm Teach Learn., 2013; 5(5): 373-380.

16. Faris RJ, MacKinnon GE, MacKinnon NJ, Kennedy PL, Perceived importance of pharmacy management skills. Am J Health-Syst Pharm., 2005; 62(10): 1067-1072.

17. Favell, Pathways to Management and Leadership 2013, (available at: www.managers.org.uk).

18. Freitas EL, Ramalho-de-Oliveira D, Critical thinking in the context of clinical practice: The need to reinvent pharmacy education. Revista Portuguesa de Educação, 2015; 28(2): 231-250.

19. Gilbert L, Community pharmacy in South Africa: A changing profession in a society in transition. Health \& Place, 1998; 4(3): 273-285.

20. Goldman M, Multiple testing, 2008, (available at: www.stat.berkeley.edu).

21. Haggaan M, Pharmacy workforce must adapt, transform, 2016, (available at: https://ajp.com.au).

22. Hibbert D, Bissell P, Ward PR, Consumerism and professional work in the community pharmacy. Sociology of Health \& Illness, 2002; 24(1): 46-65.

23. Koehler T, Brown A, A global picture of pharmacy technician and other pharmacy support workforce cadres. Res Soc Admin Pharm., 2017; 13(2): 271-279.

24. Koehler T, Brown A, Documenting the evolution of the relationship between the pharmacy support workforce 
and pharmacists to support patient care. Res Soc Admin Pharm., 2017; 13(2): 280-285.

25. Kolawole OA, Pedersen CA, Schneider PJ, Smeenk DA, Perspectives on the attributes and characteristics of pharmacy executives. Am J Health-Syst Pharm., 2002; 59(3): 278-281.

26. Lund Research, Kruskal-Wallis H Test using SPSS Statistics, 2018, (available at: https://statistics.laerd.com).

27. McPherson T, Fontane P, Pharmacists' social authority to transform community pharmacy practice. Innov Pharm., 2011; 2(2): 42-42.

28. Miller RL, Rycek RF, Fritson K, The effects of high impact learning experiences on student engagement. Procedia-Soc Behav Sci., 2011; 15: 53-59.

29. Mirică A, Higher Education - A Solution To Unemployment? Case Study: Romania. Revista Română de Statistică, 2014; 62(3): 63-75.

30. Mirică A, Toma IE, Web visibility of Romanian universities - an analysis based on website analytics and social media data, 2018, (available at: www.headconf.org).

31. Mirica A, Parvan A, Andrei A, Internationalization of Higher Education: Students' Choice at the European Level and Suitable Policies at the National Level. $26^{\text {th }}$ IBIMA conference on Innovation Management and Sustainable Economic Competitive Advantage: From Regional Development to Global Growth, 2015.

32. Monash University, Teaching tomorrow's pharmacists, 2018, (available at: www.monash.edu).

33. Morrato EH, Staffa JA, Effectiveness of risk management plans: a case study of pemoline using pharmacy claims data. Pharmacoepidem Drug Safety, 2007; 16(1): 104-112.

34. Nelson CF, A proposal for the elevation of the profession of pharmacy. J Am Pharmaceut Assoc., 1915; 4(7): 784-789.

35. O'brien EM, Outside the Classroom: Students as Employees, Volunteers, and Interns. ACE Research Briefs, 1993; 4(1): 1.

36. Paşca M D, Hancu G, Soare R, Budau M, Rusu A, Logistic and constructive attitude perception of pharmacy students towards medicine. Farmacia, 2015; 63(5): 720-725.

37. Patel A, Pharmacy: No Longer a "Second Choice" Career. Am J Pharmaceut Educ., 2007; 71(4): 1-4.

38. Pugliese RS, Girone G, Design Thinking In Pharmacy Education: Inspiring Creative Problem Solving in the Next Generation of Pharmacists. Innov Pharm., 2018, 9(2); 1-7.
39. Stancu E, Taerel A E, Soroceanu V, Rais C, Ghica M, Ethical aspects of food supplements in EU and Romania. Farmacia, 2019; 67(4): 736-742.

40. Ritzer G, The "McDonaldization" of society. $J$ Am Cult., 1983; 6(1): 100-107.

41. Rodriguez CM, A Commentary on "Undergraduate Education: The Implications of Cross-Functional Relationships in Business Marketing-The Skills of High-Performing Managers". J Business-to-Business Market., 2007; 14(1): 95-102.

42. Rollins BL, Broedel-Zaugg K, Reiselman J, Sullivan $\mathrm{D}$, Assessment of pharmacy students' perceived business management knowledge: Would exclusion of business management topics be detrimental to pharmacy curricula?. Cur Pharm Teach Learn., 2012; 4(3): 197-201.

43. Singleton JA, Nissen LM, Teaching Pharmacy students how to manage effectively in a highly competitive environment. Pharm Educ., 2014; 14(1): 21-25

44. Statista, Global pharmaceutical industry-statistics and facts. 2018, (available at: www.statista.com)

45. Stokking K, Leenders F, De Jong J, Van Tartwijk J, From student to teacher: Reducing practice shock and early dropout in the teaching profession. Eur $J$ Teach Educ., 2003; 26(3): 329-350.

46. Sylvia LM, Barr JT, Pharmacy education: what matters in learning and teaching. Jones \& Bartlett Publishers, 2010.

47. Teodorescu D, Andrei T, An examination of "citation circles" for social sciences journals in Eastern European countries. Scientometrics, 2014; 99(2): 209-231.

48. Traulsen JM, Almarsdóttir AB, Pharmaceutical policy and the pharmacy profession. Pharm World Sci., 2005; 27(5): 359-363.

49. Traulsen JM, Bissel P, 9 Theories of professions and the pharmacist. Int J Pharm Pract., 2004; 12(2): 107-114.

50. Tynjälä P, Slotte V, Nieminen J, Lonka K, Olkinuora E, From university to working life: Graduates' workplace skills in practice. In Higher education and working life: Collaborations, confrontations and challenges. Elsevier Earli, Aamasterdam, 2006; 73-88.

51. Williams KC, Williams CC, Five key ingredients for improving student motivation. Res High Educ J., 2011; 12: 104-122.

52. World Economic Forum, 2016, (available at: http://reports.weforum.org).

53. Xie Y, Reider D, Integration of innovative technologies for enhancing students' motivation for science learning and career. J Sci Educ Tech., 2014; 23(3): 370-380. 